\title{
Effect of sodium replacement in cookies on the formation of process contaminants and lipid oxidation
}

\author{
M. Mesías, F. Holgado, G. Márquez-Ruiz, F.J. Morales \\ Institute of Food Science, Technology and Nutrition, ICTAN-CSIC, José Antonio Novais 10, 28040 Madrid, \\ Spain
}

\begin{abstract}
Replacing sodium chloride by salt substitutes in the recipe is one of the main strategies applied in the food industries to prevent unwanted health effects into population. However the reduction in $\mathrm{NaCl}$ may affect to the oxidative balance and the formation of process contaminants in the food, besides of sensorial and technological aspects already known. The effect of replacing $\mathrm{NaCl}$ by different salts and two commercial saltreplacers on the formation of acrylamide and furfurals, as well as the influence on the lipid oxidation after storage was evaluated in a cookie model. Acrylamide content was reduced by up to $58 \%$ in the cookie containing $\mathrm{CaCl}_{2}$ and $35 \mathrm{e} 40 \%$ when $\mathrm{NaCl}$ was partly substituted by commercial salt replacers. Hydroxymethylfurfural and furfural content did not greatly varied by the recipe, except by $\mathrm{CaCl}_{2}$, which significantly increased the furfurals formation. Although no significant relationship was found between mineral composition and lipid oxidation after storage, products of lipids oxidation were detected. In conclusion, the type of salts used in the cookie recipe affects the extent of lipid oxidation and the formation of process contaminants and, therefore, these potential side effects should be carefully considered by the food industries when implementing sodium reduction strategies in their products.
\end{abstract}

KEYWORDS: Cookies, sodium, acrylamide, furfurals, lipid oxidation.

\section{INTRODUCTION}

There is a strong link between dietary sodium intake and increase in blood pressure, which is a major cause of cardiovascular diseases and a leading risk factor for global mortality (Strazzullo, D'Elia, Kandala, \& Cappuccio, 2009). In addition, high sodium consumption is related to other negative health effects such as gastric cancer, decreased bone mineral density and obesity (He \& MacGregor, 2008; Matkovic et al., 1995; Tsugane, Sasazuki, Kobayashi, \& Sasaki, 2004). Changes in the dietary habits of the population have led to an increase of sodium intake and a decrease of potassium intake, mainly due to the extended consumption of processed foods and the declined intake of fresh foods such as fruits and vegetables. These changes, therefore, elevate the sodium:potassium ratio, which is directly associated with the blood pressure. Elevated amounts of sodium in food are consumed far in excess of public health recommendations. In this regard, the adequate intake for sodium is set at 1.5, 1.3 and $1.2 \mathrm{~g}$ for young adults, older adults and the elderly, respectively (Institute of Medicine, 2010), whereas epidemiological studies have described sodium intakes of about $3.8 \mathrm{~g} /$ day at ages $19-30$ years for American population or even $4.8 \mathrm{~g} /$ day for European adolescents (Institute of Medicine, 2010; Lambert et al., 2004). In the past few years, several population based interventions to reduce sodium intake have been successfully implemented in various countries worldwide (WHO, 20lI). The major source of sodium in foods is common salt or sodium chloride. Therefore, the main strategy to decrease the sodium intake levels is to lower the salt content in food products. In this sense, one of the strategies applied by food industries to decrease sodium consumption is to replace $\mathrm{NaCl}$ by different salt substitutes (Dötsch et al., 2009).

Sodium chloride has been traditionally used during the manufacture of baked products as it causes several important changes in rheological, technological and sensory parameters. Rheological properties are influenced by $\mathrm{NaCl}$ content since it is involved in the structure and formation of the gluten matrix, increasing stability, flexibility and resistance of the dough and decreasing stickiness and water absorption 
(Beck, Jekle, \& Becker, 2012). Therefore, decreasing sodium chloride concentration may induce less desirable properties such as more liquid and stickier dough, lack of stability and less resistance and extensibility. Regarding sensorial characteristics, $\mathrm{NaCl}$ is related to the perception of the salty taste but also increases sweetness and masks metallic or bitter taste (Miller \& Hoseney, 2008).

On the other hand, sodium chloride is involved in the inhibition and enhancement of the formation of certain processing contaminants, such as acrylamide, 5-hydroxymethylfurfural (HMF) and furfural. Acrylamide in foods is generated during the thermal process, as a consequence of the Maillard reaction between asparagine and reducing sugars as main precursors (Stadler \& Scholz, 2004). Due to its neurotoxic and genotoxic potential, acrylamide has been classified as "probably carcinogenic to humans" (Group 2A) by the International Agency for Research on Cancer (IARC, 1994). In a similar way, HMF and furfural are formed as intermediate products of the Maillard reaction and, moreover, HMF is generated by the caramelization of sugars at high temperature (Hodge, 1953; Kroh, 1994). HMF is suspected to have genotoxic and mutagenic effects whereas furfural may lead to hepatotoxicity (EFSA, 2005). It has been reported that $\mathrm{NaCl}$ has a considerable inhibitory effect on acrylamide formation and, on the contrary, promotes the formation of HMF and furfural, which has been demonstrated both in model systems and in food models like cookies or baked products (Gökmen \& Senyuva, 2007a; Kolek, Simko, \& Simon, 2006; Levine \& Smith, 2005; Marcotullio \& De Jong, 2010).

Another aspect to take into account is the possible though practically unknown relationship between $\mathrm{NaCl}$ content and lipid oxidation. There is general agreement that potentially harmful compounds can result from lipid oxidation in foods (Dobarganes \& Márquez-Ruiz, 2003). In a food product, lipid oxidation can be promoted by copper and iron, which are well known catalysts (Schaich, 1992) that can interact with $\mathrm{NaCl}$ (Kanner, Harel, \& Jaffe, 1991). On the other hand, as $\mathrm{NaCl}$ can condition the water activity of the food product, it can affect oxidative rancidity (Kaya, Kaya, \& Oner, 1999).

In spite of the reduction of total sodium intake, the side effects related with the use of salt replacers or modifications in the $\mathrm{NaCl}$ content in the food product, such as oxidative aspects and formation of contaminants, should be carefully controlled by the food industries. The aim of the present study was to investigate the effect of different salt replacers on the formation of acrylamide, HMF and furfural in cookie models; as well as the possible influence on the development of lipid oxidation in cookie models after storage.

\section{MATERIALS AND METHODS}

\section{Reagents and chemicals}

Flour and shortening were supplied by local producers, and other ingredients were purchased from local supermarkets. Commercially available food-grade salt-replacer I (SR-I) and salt replacer II (SR-II) were acquired from national suppliers of food additives. The composition of both commercial salts is the following: (SR-I) Na: 13.8 g/l00 g, K: 20.0 g/l00 g; (SR-II) Na: 14.3 g/l00 g, K: 17.1 g/l 00 g. Acrylamide, HMF and furfural standards were purchased from Sigma (St. Louis, MO, USA). Hydrogen peroxide, nitric acid, and ethylendiaminetetraacetic acid was obtained from Panreac (Madrid, Spain). Acetonitrile, formic acid, glacial acetic acid, potassium hexacyanoferrate and zinc acetate were purchased from Merck (Darmstadt, Germany). [13C3]-acrylamide (isotopic purity 99\%) was from Cambridge Isotope Labs (Andover, MA, USA). Milli-Q water used was produced using an Elix3 Millipore water purification system coupled to a Milli-Q module (model Advantagel0) (Millipore, Molsheim, France). All other chemicals, solvents and reagents were of analytical grade. 


\section{Preparation of cookies}

Model cookies were prepared according to a recipe described in AACC (American Association of Cereal Chemists) method 10-54 (AACC, 2000) following the procedure described by Gökmen, Açar, ArribasLorenzo, and Morales (2008) with some modifications. Recipes were formulated with $130 \mathrm{~g}$ of wheat flour, $35 \mathrm{~g}$ of sucrose, $30 \mathrm{~g}$ of deionized water, $26 \mathrm{~g}$ of sunflower oil, $0.8 \mathrm{~g}$ of sodium bicarbonate, $0.4 \mathrm{~g}$ of ammonium bicarbonate and I $g$ of different salts as follows: (i) $\mathrm{NaCl}$, (ii) $\mathrm{CaCl}_{2}$, (iii) $\mathrm{KCl}$, (iv) commercial SRI, (v) commercial SR-Il, (vi) $0.5 \mathrm{~g} \mathrm{NaCl}+0.5 \mathrm{~g}$ commercial SR-I, (vii) $0.5 \mathrm{~g}$ of NaCl $+0.5 \mathrm{~g}$ of commercial SRII. The ingredients were thoroughly mixed and the dough was rolled out to disks with the diameter of 5-6 $\mathrm{cm}$ and the thickness of $2 \mathrm{~mm}$, and baked at $190^{\circ} \mathrm{C}$ for $20 \mathrm{~min}$ in a natural convection oven (Simsek Laborteknik, Turkey). Six different cookies for each formulation were prepared by duplicate.

\subsection{Determination of moisture}

Moisture was determined gravimetrically. Sample $(\mathrm{l} \mathrm{g})$ was accurately weighed $(0.1 \mathrm{mg})$ and dried to constant weight in an oven at $110^{\circ} \mathrm{C}$ for $4 \mathrm{~h}$. Percentage of moisture was calculated with the following formula: [(weight of capsule with fresh samples - weight of capsule with dry samples)/(weight of fresh samples) $] \times 100$. Analysis was done in duplicate.

\subsection{Determination of water activity (Aw)}

The water activity values of cookies were measured by an AquaLAB CX-2 (Decagon Devices Inc., Pullman, WA). The ground cookie sample was placed into the specimen holder of the device to record its water activity. The mean of two measurements was reported.

\subsection{Measurement of $\mathrm{pH}$}

Ground cookies ( $\mathrm{l} \mathrm{g}$ ) were mixed with $100 \mathrm{~mL}$ of water and vortexed for $3 \mathrm{~min}$. The mixture was held at room temperature for $\mathrm{I} h$ to separate solid and liquid phases. After carefully removing the supernatant layer, the $\mathrm{pH}$ was measured using a CG-837 pH meter (Schott, Mainz, Germany). Analysis was performed in duplicate.

\subsection{Determination of total protein content}

Total protein content was determined in the samples using an automated nitrogen analyzer (FP-2000; Dumas Leco Corp., St. Joseph, Ml), after calibration of the instrument with ethylendiaminetetraacetic acid. The nitrogen-to-protein conversion factor was $N_{-} 6.25$. The results were expressed as g of protein/ $100 \mathrm{~g}$ of product (dry matter). Analysis was done in duplicate.

\subsection{Determination of total lipid content}

Six $g$ of grounded cookie samples were weighed and total fat content was determined by Söxhlet extraction (Soxtec System HT6, Tecator AB, Höganäs, Sweden) using petroleum ether. Analysis was performed in duplicate. The results were expressed as $\mathrm{g}$ of lipid/l00 $\mathrm{g}$ of product (dry matter).

\subsection{Determination of minerals}

Samples were digested with $\mathrm{HNO}_{3}$ and $\mathrm{H}_{2} \mathrm{O}_{2}$ in a Microwave Digestion Lab station (Milestone, mod. Ethos I: Milestone, Shelton, CT I48, USA) and the digested samples were then diluted with ultrapure deionized water. The mineral content was evaluated using an Optima 4300 DV ICP-I49 OES (inductively coupled plasma optical emission spectroscope: PerkineElmer, Norwalk, CT, USA). Analyses were done in triplicate, with two different measurements from each replica. The ICPI52 MS values obtained were used to calculate 
the ion content based on the mass and dilution of each sample. The results were expressed as $\mathrm{mg} / \mathrm{l} 00 \mathrm{~g}$ of product (dry matter).

\subsection{LC-ESI-MS-MS determination of acrylamide}

Sample extraction and clean up were based on the method described by Morales, Rufián-Henares and Arribas-Lorenzo (2007) with some modifications. Powdered sample $(0.500 \mathrm{~g})$ was weighed and mixed with $9.4 \mathrm{~mL}$ of water. Mixture was spiked with $100 \mathrm{~mL}$ of a $5 \mathrm{mg} / \mathrm{mL}\left[{ }^{13} \mathrm{C}_{3}\right]$-acrylamide methanolic solution as internal standard, treated with $250 \mathrm{~mL}$ of each Carrez I and Carrez II solutions, centrifuged and cleaned-up with Oasis-HLB cartridges. An Agilent 1200 liquid chromatograph coupled to an Agilent Triple Quadrupole MS detector (Agilent Technologies, Palo Alto, CA, USA) with positive electrospray ionization was used. Sample $(10 \mathrm{~mL})$ was separated onto a Hypercarb $(50 \times 2.1 \mathrm{~mm}, 5 \mu \mathrm{m}$; Thermo Scientific, Bremen, Germany) at $30^{\circ} \mathrm{C}$ with formic acid in water $(0.2 \mathrm{~mL} / 100 \mathrm{~mL})$ at a flow rate of $0.4 \mathrm{~mL} / \mathrm{min}$. Signals at $\mathrm{m} / \mathrm{z} 72-\mathrm{m} / \mathrm{z} 55$ and $\mathrm{m} / \mathrm{z} 75-\mathrm{m} / \mathrm{z} 58$ were isolated for acrylamide and $\left[{ }^{13} \mathrm{C}_{3}\right]$-acrylamide, respectively. For the transitions $\mathrm{m} / \mathrm{z}$ $72>\mathrm{m} / \mathrm{z} 55$ and m/z $75>\mathrm{m} / \mathrm{z} 58$. I the fragmentation was set at $76 \mathrm{~V}$ and the collision energy at $8 \mathrm{~V}$.

Acrylamide was quantified with standard solutions $(5-100 \mathrm{mg} / \mathrm{L})$ spiked with $50 \mathrm{mg} / \mathrm{L}\left[{ }^{13} \mathrm{C}_{3}\right]$-acrylamide. The peak identity is confirmed by comparison of the peak area ratios for the transitions $\mathrm{m} / \mathrm{z} 72>55$ and $75>58$ from sample extracts and standard solutions, respectively. The limit of the quantitation was set at $20 \mathrm{mg} / \mathrm{kg}$. The accuracy of the results was recently demonstrated for potato crisps in an interlaboratory comparison study launched by the Food Analysis Performance Assessment Scheme (FAPAS) program (2013), yielding a z-score of 0.3 . Precision (reproducibility) was lower than 10\% and recovery between 84 and $109 \%$. Analysis was performed in duplicate and results were expressed as $\mathrm{mg} / \mathrm{kg}$ of product (dry matter).

\subsection{Determination of HMF and furfural}

HMF and furfural were determined following the HPLC method described by Rufián-Henares, DelgadoAndrade, and Morales (2009). Quantitation was conducted with a Shimadzu HPLC system, as previously described. The chromatographic separation was carried out on a Mediterranean Sea ODS-2 $(250 \times 4.0 \mathrm{~mm}$, $5 \mu \mathrm{m}$, Tecknokroma, Barcelona, Spain). The mobile phase was a mixture of acetonitrile in water $(5 \mathrm{~mL} / 100$ $\mathrm{mL}$ ) at a flow rate of $\mathrm{I} \mathrm{mL} / \mathrm{min}$ under isocratic conditions. The total running time was $20 \mathrm{~min}$, the UV detector was set at $280 \mathrm{~nm}$ and $20 \mathrm{~mL}$ of the extract was injected. HMF and furfural were quantified using the external standard. The limit of quantification was set at $0.5 \mathrm{mg} / 100 \mathrm{~mL}$ and $0.01 \mathrm{mg} / 100 \mathrm{~mL}$ for HMF and furfural, respectively. Analyses were done in duplicate and results were expressed as $\mathrm{mg} / \mathrm{kg}$ of product (dry matter).

\section{I I. Storage of cookies}

Cookies ( $n=3$ ) were packed in plastic bags and stored at $25-30^{\circ} \mathrm{C}$ in the dark during 60 days without oxygen restriction in order to evaluate oxidative stability. These conditions, which are not the conventional ones, were performed with the aim of favoring the oxidation process. Peroxide value and determination of polymers were performed both in the initial cookies and after the storage period.

\subsection{Determination of peroxide value}

Peroxide value was determined in lipids extracted from stored and non-stored cookies by the iodometric assay following IUPAC standard method 2.50I (IUPAC, 1992). Analysis was performed in duplicate.

\subsection{Determination of polymers}


Aliquots of $50 \mathrm{mg}$ lipids extracted from stored and non-stored cookies were dissolved in I $\mathrm{mL}$ tetrahydrofuran for direct analysis by high-performance size-exclusion chromatography (HPSEC). A chromatograph equipped with a Rheodyne 7725i injector with a 10-mL sample loop, a Knauer 120 HPLC pump (Knauer, Berlin, Germany) and a Merck L-7490 refractive index detector (Merck, Darmstadt, Germany) was used. The separation was performed on two 100 and $500 \AA$ Ultrastyragel columns $(25 \mathrm{~cm} \times$ $0.77 \mathrm{~cm}$ i.d.) packed with porous, highly cross linked styrene-divinylbenzene copolymers (film thickness: 10 $\mathrm{mm}$ ) (HewlettePackard, Avondale, PA, USA) connected in series, with tetrahydrofuran $(1 \mathrm{~mL} / \mathrm{min})$ as the mobile phase (Márquez-Ruiz \& Dobarganes, 2007). The groups of compounds quantified were triacylglycerol dimers and higher oligomers. The sum of dimers and higher oligomers will be referred to as total polymers. Analysis was performed in duplicate.

\section{I4. Statistical analysis}

Statistical analyses were performed using Statgraphics Centurion XV (Herndon, VA, USA). Data were expressed as mean \pm standard deviation (SD). Analysis of variance (ANOVA) and the least significant difference (LSD) test were applied to determine differences between means. Differences were considered to be significant at $p<0.05$. Relationships between the different parameters analyzed were evaluated by computing Pearson linear correlation coefficients at the $p<0.05$ confidence level.

\section{RESULTS AND DISCUSSION}

In the present study, seven model cookies were prepared. Cookies were formulated with the same recipes except for the salt composition in order to evaluate the effect on the formation of acrylamide, HMF and furfural. Table I describes the characterization of the different cookie recipes. Moisture of the samples ranged from 1.98 to $4.05 \mathrm{~g} / \mathrm{l} 00 \mathrm{~g}$, the cookie containing $\mathrm{CaCl}_{2}$ exhibiting the highest moisture content. Very similar behavior was observed in $\mathrm{Aw}$, which ranged from 0.06 to 0.02 . The $\mathrm{pH}$ values, assessed in cookie ranged from 7.04 to 9.66; the cookie containing $\mathrm{CaCl}_{2}$ showed the lowest $\mathrm{pH}$ and the recipe containing $\mathrm{NaCl}+$ SR-I the highest one. Results for protein content $(7.05-7.96 \mathrm{~g} / \mathrm{l} 00 \mathrm{~g})$ and total lipid content (10.8$13.9 \mathrm{~g} / 100 \mathrm{~g}$ ) were very similar among recipes and only minor differences were observed.

The mineral composition of the cookies is summarized in Table 2. Since $\mathrm{Na}^{+}$and $\mathrm{K}^{+}$were provided by the majority of the salts, these were the main cations found in the samples, though in different proportions depending on the salt added to the formulations. As expected, the highest calcium content was the sample containing $\mathrm{CaCl}_{2}$. There were very low levels for the rest of the elements (magnesium, copper, iron and zinc) as they are trace elements found in the salts or wheat flour added to the dough. Recipes formulated with SR-I and SR-II contained significantly less sodium and more potassium than recipes formulated with $\mathrm{NaCl}$. Among them, SR-I incorporate less sodium and more potassium and, on the contrary, SR-II incorporates less potassium and more sodium. The rest of minerals can be considered similar for both salts and very close to those from $\mathrm{NaCl}$.

The effect of the partial or total replacement of $\mathrm{NaCl}$ in the cookie recipe by different salts on acrylamide, HMF and furfural formation during baking was studied. Fig. I shows the changes in acrylamide content in the different cookie models baked at $190^{\circ} \mathrm{C}$ for $20 \mathrm{~min}$. Acrylamide levels ranged from $153.4 \mathrm{mg} / \mathrm{kg}$ to 380.8 $\mathrm{mg} / \mathrm{kg}$, in line with the concentrations described in cookies with similar formulations and treatments (Açar, Pollio, Di Monaco, Fogliano, \& Gökmen, 2012; Fiore et al., 2012; Quarta \& Anese, 2010). It is important to highlight that cookie recipes and baking conditions were conventional, and drastic baking conditions or incorporation of other ingredients to promote acrylamide or furfurals formation were not used. Indeed, 
acrylamide levels were lower than the reference threshold value pointed out by the European Commission $(500 \mathrm{mg} / \mathrm{kg})$ (European Commission, 2013).

The highest levels of acrylamide were observed in cookies containing $\mathrm{NaCl}, \mathrm{KCl}$ and SR-I. It may be deduced consequently that these salts were the least effective ingredients for reducing acrylamide formation under our experimental conditions. Acrylamide concentration decreased by up to $17 \%$ when sodium chloride was replaced by commercial SR-II, whereas reductions of 35 and 40\% were observed when cookies contained a mixture of $\mathrm{NaCl}+\mathrm{SR}-\mathrm{I}$ and $\mathrm{NaCl}+\mathrm{SR}-\mathrm{Il}$, respectively. This fact could be explained by a possible synergic effect between salts when these are mixed together in the same dough, which agrees with the observations of Quarta and Anese (2010). These authors did not observe any decrease in acrylamide formation in cookies containing $\mathrm{CaCl}_{2}$ or $\mathrm{MgCl}_{2}$ in the cookies dough but in contrast, a $60 \%$ reduction in acrylamide was obtained when these salts were added in combination. The lowest acrylamide content was observed in the cookie formulated with $\mathrm{CaCl}_{2}$, where the concentration was $58 \%$ lower than the content of the contaminant in the formulation with $\mathrm{NaCl}$. Opposite results were found for the $\mathrm{HMF}$ and furfural formation in the cookie models (Figs. 2 and 3). In fact, both HMF and furfural were significantly increased in the presence of $\mathrm{CaCl}_{2}$, reaching values of even $8500 \mathrm{mg} / \mathrm{kg}$ and $200 \mathrm{mg} / \mathrm{kg}$, respectively. The rest of the cookies showed much lower results in HMF (range: $5.7-20.2 \mathrm{mg} / \mathrm{kg}$ ) and furfural content (range: $0.9-1.8 \mathrm{mg} / \mathrm{kg}$ ), in line with data reported in previous studies (average of $14.4 \mathrm{mg} / \mathrm{kg}$, range of $3.1-182.5 \mathrm{mg} / \mathrm{kg}$ for HMF in commercial cookies marketed in Spain) (Delgado-Andrade, Rufián-Henares, \& Morales, 2009).

Results observed in the present study are in line with other reports. The higher effectiveness of divalent cations $\left(\mathrm{Ca}^{2+}, \mathrm{Mg}^{2+}\right)$ in reducing acrylamide formation in comparison with monovalent ones $\left(\mathrm{Na}^{+}, \mathrm{K}^{+}\right)$has been previously stated in model systems and food models (Gökmen \& Senyuva, 2007a, 2007b; Mestdagh et al., 2008; Quarta \& Anese, 2010). For instance, Mestdagh et al. (2008) reported an acrylamide content 43\% lower when $\mathrm{CaCl}_{2}$ was added to a potato model system heated at $170^{\circ} \mathrm{C}$ for 6 min compared with $\mathrm{NaCl}$ in the same proportion. Likewise, Kukuroá, Ciesarová, Bednáriková, and Marková (2009) concluded that $\mathrm{CaCl}_{2}$ was the most effective acrylamide formation inhibitor in cereal matrices in comparison with other inorganic salts. Reductions of $60 \%$ and $36 \%$ in acrylamide formation have also been described when calcium chloride was added to dough in bakery products and in cooked wheat products, respectively (Levine \& Ryan, 2009; Sadd, Hamlet, \& Liang, 2008). On the contrary, the addition of $\mathrm{Ca}^{2+}$ or $\mathrm{Mg}^{2+}$ to glucose-asparagine model systems increased the development of HMF and furfural (Gökmen \& Senyuva, 2007a; Quarta \& Anese, 2010), although contradictory results have been observed when $\mathrm{Ca}^{2+}$ is added to the recipe of a food model. Quarta and Anese (2010) did not find differences in HMF content when cookies with added $\mathrm{CaCl}_{2}$ in the recipe and enriched with asparagine were compared with cookies containing $\mathrm{NaCl}$. However, several authors have shown that the use of calcium derivatives may significantly increase HMF concentrations in cookies (Açar et al., 2012; Fiore et al., 2012). This fact is based on the theory that divalent metal ions added to the food product may improve high-temperature stability to asparagine/matrix interactions, decreasing the availability for reaction with carbonyl precursors to generate acrylamide (Lindsay \& Jang, 2005). Consequently, formation of the Schiff base, which is an essential intermediate of acrylamide formation, is prevented and the reaction path changes toward the dehydration of glucose, leading to the formation of HMF and furfural (Gökmen \& Senyuva, 2007a).

In the present study, a negative correlation was found between the amount of calcium in the recipe of the cookies and acrylamide development during baking at $190^{\circ} \mathrm{C}$ for $20 \min \left(r^{2}=-0.7082, p=0.0046\right)$. Contrarily, the positive effect of calcium on HMF and furfural formation is clearly depicted in Figs. 2 and 3. Therefore, it is possible that the calcium content significantly influenced acrylamide, HMF and furfural 
formation in cookies. Regarding the sodium content, we did not find a direct relationship between the amounts of $\mathrm{Na}^{+}$included in the formulation and the development of acrylamide, $\mathrm{HMF}$ and furfural formation. Nevertheless samples with I $\mathrm{g}$ of $\mathrm{NaCl}$ in the formulation exhibited higher levels of the three contaminants when compared with those containing only $0.5 \mathrm{~g}$ of $\mathrm{NaCl}$. These results agree with previous studies reporting that the presence of $\mathrm{NaCl}$ enhances the formation of $\mathrm{HMF}$ in model systems (Gökmen \& Senyuva, 2007a) and model cookies (Fiore et al., 20I2). With respect to acrylamide, Fiore et al. (20I2) reported that the formation of this contaminant was not significantly modified by the presence of salt. Claus, Mongili, Weisz, Schieber, and Carle (2008) did not observe a direct relationship between salt content and acrylamide formation either, when evaluating the effect of different concentrations of salt (I-5\%) in bread rolls. Furthermore, it is not expected to find a relationship between minerals other than calcium, and the development of acrylamide and HMF in our experiment.

Another aspect to take into account is the fact that acrylamide, HMF and furfural formation can be affected by the $\mathrm{pH}$ of the system. It has been suggested that by decreasing the $\mathrm{pH}$ in processed foods the acrylamide content would be reduced (Sadd et al., 2008) whereas, to the contrary, HMF formation is favored by low $\mathrm{pH}$ values (Quarta \& Anese, 2010). Addition of salts can modify this parameter and therefore, could be related with the reduction or increase of the contaminants in the food product. According to Hughes, Grant, and Faulks (1975), the addition of metal cations to certain foods may cause a decrease in the $\mathrm{pH}$. In this respect, Quarta and Anese (2010) found that $\mathrm{Ca} 2 \mathrm{p}$ was capable of inducing significant $\mathrm{pH}$ reduction in model systems. For this reason, it has been questioned whether the inhibition of the formation of acrylamide when $\mathrm{Ca}^{2+}$ is added to the system is due to the ions or to the drop in the $\mathrm{pH}$ (Mestdagh et al., 2008). In the present study a positive correlation among $\mathrm{pH}$ and sodium content was found $\left(r^{2}=0.749, \mathrm{p}=0.0020\right)$, and at the same time, $\mathrm{pH}$ was negatively correlated with calcium content $\left(r^{2}=-0.834, \mathrm{p}=0.0002\right)$. The sample which presented the lowest $\mathrm{pH}$ value coincided with the highest calcium content and, as mentioned before, with the lowest levels of acrylamide and the highest levels of HMF and furfural. Consequently, we cannot discard the possibility that the inhibition or the enhancement of contaminants formation could be affected by changes in the $\mathrm{pH}$ as a consequence of the cations added to the systems.

On the other hand, cookies were stored for 60 days in order to determine oxidative stability. Evaluation of the state of oxidation was approached through determination of primary oxidation products (measured by peroxide value) and, complementarily, by quantification of secondary oxidation compounds (dimers and higher oligomers). Results are presented in Table 3. In general, oxidation levels in cookies stored for 60 days were high, especially as peroxide values are concerned, quite in contrast with the low values found in nonstored cookies, i.e., below 10 meq $\mathrm{O}_{2} / \mathrm{kg}$ lipids. Levels of polymerization compounds were consistent with peroxide values and indicated that non-stored cookies did not contain oxidation compounds whereas in stored cookies the least oxidized sample corresponded to SR-I followed by $\mathrm{NaCl}+\mathrm{SR}-\mathrm{I}$. Fig. 4 illustrated the great differences found between such samples in terms of total polymers (dimers plus higher oligomers). Groups of triacylglycerol compounds eluted in decreasing order of molecular weight, i.e., higher oligomers, dimers and monomers. In contrast, neither SR-II nor addition of SR-II to $\mathrm{NaCl}$ resulted in improved oxidative stability. In fact, the greatest levels of oxidation were found, in the following decreasing order, for $\mathrm{NaCl}, \mathrm{NaCl}+$ SRII, SR-II and $\mathrm{CaCl}_{2}$.

The effect of salts on lipid oxidation has been extensively evaluated in meat and fish products and results obtained indicated that $\mathrm{NaCl}$ was prooxidant because of its capacity to displace iron compounds from binding proteins in membranes (Kanner et al., 1991). However, to our knowledge, there is no published report on the effect of salts on lipid oxidation in cookies. Development of lipid oxidation in foods depends 
on many variables, including those intrinsic of the lipids, such as unsaturation degree and antioxidant content and others such as prooxidants, interaction of lipids with other foods components, physical state and distribution of lipids in foods and water activity (Márquez-Ruiz, Holgado, \& Velasco, 2013). Since all ingredients of cookies and conditions for preparation and storage of cookies were the same for all samples, occurrence of metals of potential prooxidative action coming from the salts added could have accounted for the differences found. It is well known that copper and iron act as catalysts in the initiation phase of lipid oxidation, mainly via electron transfer and formation of alkyl radicals (Schaich, 1992). However, no relationship was found between the levels of copper and iron (Table 2) and oxidation levels. Clearly, other factors not examined in this work may have had an influence, such as water activity in turn dependent on the salt used, or quelation of metals by negligible amounts of unknown components included in the salts.

\section{CONCLUSIONS}

The effect of different salt replacers on the formation of acrylamide, HMF and furfural in cookie models was evaluated. As expected, the lowest acrylamide content was observed in the cookie containing $\mathrm{CaCl}_{2}$, but reductions of 35 and $40 \%$ were observed when $\mathrm{NaCl}$ was partly substituted with commercial salt-replacers. HMF and furfural formation were affected in less extent by the composition of the salts added, except for $\mathrm{CaCl}_{2}$, which significantly increased the formation of these contaminants. On the other hand the influence of the replacement of $\mathrm{NaCl}$ on the development of lipid oxidation in cookie models after storage was assessed. Different oxidation levels, including formation of oligomers, were observed in the cookies, however, no relationship was found between mineral composition and lipid oxidation, which may suggest that other factors may have had an influence in the oxidation. In conclusion, changes in the mineral composition during cookie formulation has a direct effect on the extent of lipid oxidation and formation of contaminants and, therefore, these potential side effects should be carefully controlled by the food industries before adopting sodium reduction strategies.

\section{CONFLICT OF INTEREST}

The authors declare that they have no conflict of interest.

\section{ACKNOWLEDGMENT}

This research was partly funded by the grant AGRI464-ANALISYC-II (CAM) and PIE20I370E027 (CSIC). Authors wish to thank Ms. I. Alvarez, Ms. P. Moreno, Mr. G. Guerrero, and Mr. MA. Martinez for their technical assistance with acrylamide, protein, and mineral analyses.

\section{REFERENCES}

AACC. (2000). Approved methods of the American Association of Cereal Chemists (10 th ed.). St. Paul, Minnesota: Association of Cereal Chemists.

Açar, Ö.Ç., Pollio, M., Di Monaco, R., Fogliano, V., \& Gökmen, V. (2012). Effect of calcium on acrylamide level and sensory properties of cookies. Food and Bioprocess Technology, 5, 519-526.

Beck, M., Jekle, M., \& Becker, T. (20I2). Impact of sodium chloride on wheat flour dough for yeast-leavened products. I. Rheological attributes. Journal of the Science of Food and Agriculture, 92, 585-592.

Claus, A., Mongili, M., Weisz, G., Schieber, A., \& Carle, R. (2008). Impact of formulation and technological factors on the acrylamide content of wheat bread and bread rolls. Journal of Cereal Science, 47, 546-554.

Delgado-Andrade, C., Rufián-Henares, J. A., \& Morales, F. J. (2009). Hydroxymethylfurfural in commercial biscuits marketed in Spain. Journal of Food and Nutrition Research, 48, 14-19.

Dobarganes, M. C., \& M_arquez-Ruiz, G. (2003). Oxidised fats in foods. Current Opinion in Clinical Nutrition and Metabolic Care, 6, 157-163. 
D€otsch, M., Busch, J., Batenburg, M., Liem, G., Tareilus, E., Mueller, R., et al. (2009). Strategies to reduce sodium consumption: a food industry perspective. Critical Reviews in Food Science and Nutrition, 49, 84I851.

EFSA. (2005). Opinion of the Scientific Panel on food additives, flavourings, processing aids and materials in contact with food (AFC) related to Flavouring Group Evaluation I3 (FGE. I3); Furfuryl and furan derivatives with and without additional side-chain substituents and heteroatoms from chemical group 14. In EFSA scientific documents [online]. Parma: European Food Safety Authority. Available at: http://www.efsa.europa.eu/en/scdocs/scdoc/215.htm Accessed 14.04.14.

European Commission. (2013). Commission Recommendation of 8 November 2013 on investigations into the levels of acrylamide in food. Available at: http://www.fsai.ie/uploadedFiles/Recomm_2013_647.pdf Accessed 20.08.14.

Fiore, A., Troise, A. D., Mogol, B. A., Roullier, V., Gourdon, A., El Mafadi Jian, S., et al. (2012). Controlling the Maillard reaction by reactant encapsulation: sodium chloride in cookies. Journal of Agriculture and Food Chemistry, 60, 10808-10814.

Gökmen, V., Açar, Ö. C., Arribas-Lorenzo, G., \& Morales, F. J. (2008). Investigating the correlation between acrylamide content and browning ratio of model cookies. Journal of Food Engineering, 87, 380-385.

Gökmen, V., \& Senyuva, H. Z. (2007a). Effects of some cations on the formation of acrylamide and furfurals in glucoseeasparagine model system. European Food Research and Technology, 225, 8I5-820.

Gökmen, V., \& Senyuva, H. Z. (2007b). Acrylamide formation is prevented by divalent cations during the Maillard reaction. Food Chemistry, 103, 196-203.

He, F., \& MacGregor, G. (2008). A comprehensive review on salt and health and current experience of worldwide salt reduction programmes. Journal of Human Hypertension, 23, 363-384.

Hodge, J. E. (1953). Chemistry of Browning reactions in model systems. Journal of Agricultural and Food Chemistry, I, 928-943.

Hughes, J. C., Grant, A., \& Faulks, R. M. (1975). Texture of cooked potatoes: the effect of ions and pH on the compressive strength of cooked potatoes. Journal of the Science of Food Agriculture, 26, 739-748.

IARC. (1994). Monographs on the evaluation of carcinogenic risks to humans: Some industrial chemicals, 60 PP. 389e433). Lyon, France: International Agency for Research on Cancer.

Institute of Medicine. (2010). Strategies to reduce sodium intake in the United States. Committee on Strategies to Reduce Sodium Intake. In J. E. Henney, C. L. Taylor, \& C. S. Boon (Eds.). Washington, DC: National Academies Press.

IUPAC (International Union of Pure and Applied Chemistry). (1992). Standard methods for the analysis of oils, fats and derivatives (7th ed.). Oxford, UK: Blackwell Scientific Publications.

Kanner, J., Harel, S., \& Jaffe, R. (199I). Lipid peroxidation of muscle food as affected by $\mathrm{NaCl}$. Journal of Agriculture and Food Chemistry, 39, 1017-1021.

Kaya, S., Kaya, A., \& Oner, M. D. (1999). The effect of salt concentration on rancidity in Gaziantep cheese. Journal of the Science of Food and Agriculture, 79, 213-219.

Kolek, E., Simko, P., \& Simon, P. (2006). Inhibition of acrylamide formation in asparagine/D-glucose model system by $\mathrm{NaCl}$ addition. European Food Research and Technology, 224, 283-284.

Kroh, L. W. (1994). Caramelisation in food and beverages. Food Chemistry, 5I, 373-379.

Kukurov_a, K., Ciesarov_a, Z., Bedn_arikov_a, A., \& Markov_a, L. (2009). Effect of inorganic salts on acrylamide formation in cereal matrices. Czech Journal of Food Science, 27, S425-S428.

Lambert, J., Agostoni, C., Elmadfa, I., Hulshof, K., Krause, E., Livingstone, B., et al. (2004). Dietary intake and nutritional status of children and adolescents in Europe. British Journal of Nutrition, 92, SI47-S2II.

Levine, R. A., \& Smith, R. E. (2005). Sources of variability of acrylamide levels in a cracker model. Journal of Agricultural and Food Chemistry, 53, 4410-4416. 
Levine, R. A., \& Ryan, S. M. (2009). Determining the effect of calcium cations on acrylamide formation in cooked wheat products using a model system. Journal of Agricultural and Food Chemistry, 57, 6823-6829.

Lindsay, R. C., \& Jang, S. (2005). Chemical intervention strategies for substantial suppression of acrylamide formation in fried potato products. Advances in Experimental Medicine and Biology, 56I, 393-404.

Marcotullio, G., \& De Jong, W. (2010). Chloride ions enhance furfural formation from D-xylose in dilute aqueous acidic solutions. Green Chemistry, 12, 1739-1746.

Márquez-Ruiz, G., \& Dobarganes, M. C. (2007). High-performance size-exclusion chromatography for lipid analysis in organic media. In Lipid analysis and lipidomics. New techniques and applications (pp. 205-238). Champaign, IL, USA: AOCS Press.

Márquez-Ruiz, G., Holgado, F., \& Velasco, J. (20/3). Mechanisms of oxidation in food lipids. In G. Bartosz (Ed.), Food oxidants and antioxidants: Chemical, biological, and functional properties (Pp. 80ell3). Boca Raton, USA: CRC Press.

Matkovic, V., llich, J. Z., Andon, M. B., Hisch, L. C., Tzagournis, M. A., Lagger, B. J., et al. (1995). Urinary calcium, sodium, and bone mass of young females. The American Journal of Clinical Nutrition, 62, 4I7-425.

Mestdagh, F., Maertens, J., Cucu, T., Delporte, K., Van Peteghem, C., \& De Meulenaer, B. (2008). Impact of additives to lower the formation of acrylamide in a potato model system through $\mathrm{pH}$ reduction and other mechanisms. Food Chemistry, 107, 26-31.

Miller, R. A., \& Hoseney, R. C. (2008). Role of salt in baking. Cereal Foods World, 53, 4-6.

Morales, F. J., Rufian-Henares, J. A., \& Arribas-Lorenzo, G. (2007). Acrylamide content of selected Spanish foods: Survey of biscuits and bread derivatives. Food Additives and Contaminants, 24, 343-350.

Quarta, B., \& Anese, M. (2010). The effect of salts on acrylamide and 5-hydroxymethylfurfural formation in glucose-asparagine model solutions and biscuits. Journal of Food and Nutrition Research, 49, 69-77.

Rufián-Henares, J. A., Delgado-Andrade, C., \& Morales, F. J. (2009). Assessing the Maillard reaction development during the toasting process of common flours employed by the cereal products industry. Food Chemistry, I14, 93-99.

Sadd, P. A., Hamlet, C. G., \& Liang, L. (2008). Effectiveness of methods for reducing acrylamide in bakery products. Journal of Agriculture and Food Chemistry, 56, 6154-616I.

Schaich, K. M. (1992). Metals and lipid oxidation. Contemporary issues. Lipids, 27, 209-218.

Stadler, R. H., \& Scholz, G. (2004). Acrylamide: an update on current knowledge in analysis, levels in food, mechanisms of formation, and potential strategies of control. Nutrition Reviews, 62, 449-467.

Strazzullo, P., D'Elia, L., Kandala, N. B., \& Cappuccio, F. (2009). Salt intake, stroke, and cardiovascular disease: metaanalysis of prospective studies. British Medical Journal, 339, b4567.

Tsugane, S., Sasazuki, S., Kobayashi, M., \& Sasaki, S. (2004). Salt and salted food intake and subsequent risk of gastric cancer among middle e aged Japanese men and women. British Journal of Cancer, 90, I28-134.

WHO. (20II). Strategies to monitor and evaluate population sodium consumption and sources of sodium in the diet: Report of a joint technical meeting convened by WHO and the Government of Canada. World Health Organization. Available at: http://whqlibdoc.who.int/publications/201 I/9789241501699_eng.pdf?ua=I Accessed 09.04.14. 


\section{FIGURES AND TABLES}

Table I. Characterization of cookie models with different salts added in the formulations. Cookies were baked at $190^{\circ} \mathrm{C}$ for $20 \mathrm{~min}$.

\begin{tabular}{llllll}
\hline Samples & Moisture $(\mathrm{g} / 100 \mathrm{~g})$ & Water activity & $\mathrm{pH}$ & Protein $(\mathrm{g} / 100 \mathrm{~g} \mathrm{~d}$.m. $)$ & Total lipids $(\mathrm{g} / 100 \mathrm{~g}$ d.m. $)$ \\
\hline $\mathrm{NaCl}$ & $2.56 \pm 0.03^{\mathrm{b}}$ & $0.11 \pm 0.00^{\mathrm{b}}$ & $9.62 \pm 0.06^{\mathrm{e}}$ & $7.23 \pm 0.00^{\mathrm{ab}}$ & $10.8 \pm 1.65^{\mathrm{a}}$ \\
$\mathrm{CaCl}{ }_{2}$ & $4.05 \pm 0.02^{\mathrm{e}}$ & $0.20 \pm 0.00^{\mathrm{f}}$ & $7.04 \pm 0.03^{\mathrm{b}}$ & $7.96 \pm 0.34^{\mathrm{c}}$ & $11.3 \pm 0.35^{\mathrm{a}}$ \\
$\mathrm{KCl}$ & $3.87 \pm 0.03^{\mathrm{d}}$ & $0.18 \pm 0.00^{\mathrm{e}}$ & $8.17 \pm 0.06^{\mathrm{a}}$ & $7.40 \pm 0.03^{\mathrm{abc}}$ & $12.5 \pm 0.12^{\mathrm{a}}$ \\
$\mathrm{SR}-\mathrm{I}$ & $1.98 \pm 0.09^{\mathrm{a}}$ & $0.06 \pm 0.00^{\mathrm{a}}$ & $8.87 \pm 0.04^{\mathrm{c}}$ & $7.76 \pm 0.54^{\mathrm{bc}}$ & $13.6 \pm 0.82^{\mathrm{a}}$ \\
$\mathrm{SR}-\mathrm{II}$ & $2.08 \pm 0.07^{\mathrm{a}}$ & $0.06 \pm 0.00^{\mathrm{a}}$ & $9.62 \pm 0.03^{\mathrm{e}}$ & $7.05 \pm 0.05^{\mathrm{a}}$ & $12.6 \pm 1.06^{\mathrm{a}}$ \\
$\mathrm{NaCl}+\mathrm{SR}-\mathrm{I}$ & $3.83 \pm 0.01^{\mathrm{d}}$ & $0.16 \pm 0.00^{\mathrm{d}}$ & $9.66 \pm 0.01^{\mathrm{e}}$ & $7.26 \pm 0.02^{\mathrm{ab}}$ & $13.3 \pm 0.82^{\mathrm{a}}$ \\
$\mathrm{NaCl}+$ SR-II & $3.21 \pm 0.12^{\mathrm{c}}$ & $0.14 \pm 0.00^{\mathrm{c}}$ & $9.30 \pm 0.04^{\mathrm{d}}$ & $7.06 \pm 0.03^{\mathrm{a}}$ & $13.9 \pm 0.85^{\mathrm{a}}$ \\
\hline
\end{tabular}

Table 2. Mineral composition ( $\mathrm{mg} / \mathrm{l00} \mathrm{g}$ d.m.) of cookie models with different salts added in the formulations. Cookies were baked at $190^{\circ} \mathrm{C}$ for $20 \mathrm{~min}$.

\begin{tabular}{|c|c|c|c|c|c|c|c|}
\hline Samples & $\mathrm{Na}$ & $\mathrm{K}$ & $\mathrm{Ca}$ & $\mathrm{Mg}$ & $\mathrm{Cu}$ & $\mathrm{Fe}$ & $\mathrm{Zn}$ \\
\hline $\mathrm{NaCl}$ & $346.5 \pm 0.5^{\mathrm{d}}$ & $118.0 \pm 1.0^{\circ}$ & $16.6 \pm 2.5^{a}$ & $15.4 \pm 0.0^{\mathrm{a}}$ & $1.0 \pm 0.1^{\mathrm{abc}}$ & $0.6 \pm 0.4^{a}$ & $0.2 \pm 0.0^{\mathrm{b}}$ \\
\hline $\mathrm{CaCl}_{2}$ & $103.1 \pm 2.2^{\mathrm{a}}$ & $129.1 \pm 28.8^{\mathrm{a}}$ & $326.7 \pm 2.0^{c}$ & $16.4 \pm 1.2^{\mathrm{ab}}$ & $1.2 \pm 0.0^{\mathrm{abc}}$ & $1.5 \pm 0.6^{\mathrm{a}}$ & $<0.15^{\mathrm{a}}$ \\
\hline $\mathrm{KCl}$ & $94.4 \pm 7.7^{\mathrm{a}}$ & $606.4 \pm 9.3^{e}$ & $19.7 \pm 2.9^{\mathrm{a}}$ & $17.3 \pm 0.4^{\mathrm{bcd}}$ & $1.3 \pm 0.3^{b c}$ & $1.8 \pm 1.0^{\mathrm{a}}$ & $<0.15^{\mathrm{a}}$ \\
\hline SR-I & $177.4 \pm 13.7^{b}$ & $231.7 \pm 2.1^{b c}$ & $16.5 \pm 0.4^{\mathrm{a}}$ & $17.8 \pm 0.0^{\mathrm{cd}}$ & $0.7 \pm 0.3^{\mathrm{ab}}$ & $1.0 \pm 0.0^{\mathrm{a}}$ & $<0.15^{\mathrm{a}}$ \\
\hline SR-II & $283.3 \pm 5.2^{c}$ & $188.0 \pm 10.9^{\mathrm{b}}$ & $17.6 \pm 2.5^{\mathrm{a}}$ & $16.6 \pm 0.3^{\mathrm{abc}}$ & $0.5 \pm 0.1^{\mathrm{a}}$ & $1.2 \pm 0.1^{\mathrm{a}}$ & $0.3 \pm 0.1^{c}$ \\
\hline $\mathrm{NaCl}+\mathrm{SR}-\mathrm{I}$ & $402.1 \pm 17.2^{\mathrm{e}}$ & $280.2 \pm 15.9^{c}$ & $21.3 \pm 2.2^{\mathrm{a}}$ & $18.2 \pm 0.7^{\mathrm{d}}$ & $0.6 \pm 0.2^{\mathrm{a}}$ & $0.3 \pm 0.1^{\mathrm{a}}$ & $0.3 \pm 0.1^{c}$ \\
\hline $\mathrm{NaCl}+\mathrm{SR}-\mathrm{II}$ & $540.8 \pm 25.7^{f}$ & $379.2 \pm 34.8^{\mathrm{d}}$ & $27.0 \pm 0.3^{\mathrm{b}}$ & $16.6 \pm 0.7^{\mathrm{abc}}$ & $1.5 \pm 0.5^{c}$ & $1.6 \pm 0.5^{\mathrm{a}}$ & $<0.15^{\mathrm{a}}$ \\
\hline
\end{tabular}

Results are expressed in dry matter (d.m.). Values are mean $\pm \mathrm{SD}(n=2)$. Different letters in the same column mean significant differences $(p<0.05)$. SR: salt replacer.

Table 3. Oxidative parameters in extracted lipids from cookie models stored at $25-30^{\circ} \mathrm{C}$ for 60 days.

\begin{tabular}{lcrll}
\hline Samples & $\begin{array}{l}\text { Peroxide value } \\
\text { (meq } \mathrm{O}_{2} / \mathrm{kg} \text { lipids) }\end{array}$ & $\begin{array}{c}\text { Dimers (wt\% lipids) } \\
\text { on ligomers }\end{array}$ & $\begin{array}{l}\text { Ootal polymers } \\
\text { (wt\% on lipids) } \\
\text { (wt\% on lipids) }\end{array}$ \\
\hline $\mathrm{NaCl}$ & $3961 \pm 14.8^{\mathrm{g}}$ & $16.4 \pm 0.7^{\mathrm{e}}$ & $5.7 \pm 1.1^{\mathrm{b}}$ & $22.1 \pm 1.8^{\mathrm{f}}$ \\
$\mathrm{CaCl}$ & $2433 \pm 138.6^{\mathrm{e}}$ & $8.2 \pm 0.2^{\mathrm{c}}$ & $3.2 \pm 0.3^{\mathrm{a}}$ & $11.4 \pm 0.5^{\mathrm{c}}$ \\
$\mathrm{KCl}$ & $805 \pm 178.2^{\mathrm{c}}$ & $3.7 \pm 0.1^{\mathrm{b}}$ & - & $3.7 \pm 0.1^{\mathrm{b}}$ \\
$\mathrm{SR}-\mathrm{I}$ & $393 \pm 1.4^{\mathrm{a}}$ & $1.9 \pm 0.1^{\mathrm{a}}$ & - & $1.9 \pm 0.1^{\mathrm{a}}$ \\
$\mathrm{SR}-\mathrm{II}$ & $2137 \pm 17.7^{\mathrm{d}}$ & $12.3 \pm 0.5^{\mathrm{d}}$ & $3.5 \pm 0.3^{\mathrm{a}}$ & $15.8 \pm 0.6^{\mathrm{d}}$ \\
$\mathrm{NaCl}+\mathrm{SR}-\mathrm{I}$ & $537 \pm 21.2^{\mathrm{b}}$ & $2.0 \pm 0.1^{\mathrm{a}}$ & - & $2.0 \pm 0.1^{\mathrm{a}}$ \\
$\mathrm{NaCl}+\mathrm{SR}-\mathrm{II}$ & $3007 \pm 201.5^{\mathrm{f}}$ & $12.8 \pm 0.4^{\mathrm{d}}$ & $6.0 \pm 0.6^{\mathrm{b}}$ & $18.8 \pm 0.7^{\mathrm{e}}$ \\
\hline
\end{tabular}

Values are mean $\pm \mathrm{SD}(n=2)$. Different letters in the same column mean significant differences $(p<0.05)$. SR: salt replacer, Wt: weight. 
Figure I. Acrylamide concentration ( $\mathrm{mg} / \mathrm{kg} \mathrm{d.m}$.) in cookies baked at $190^{\circ} \mathrm{C}$ for $20 \mathrm{~min}$, as influenced by different salts added in the formulations. Results are expressed in dry matter (d.m.). Values are mean \pm SD $(n=2)$. Different letters mean significant differences $(p<0.05)$. SR: salt replacer.

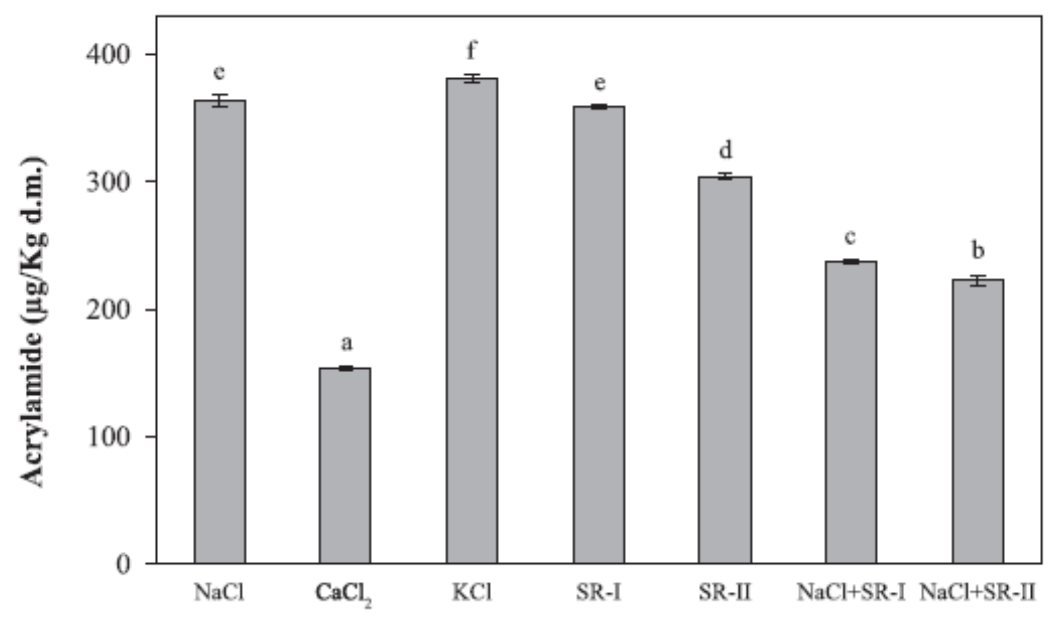

Figure 2. HMF concentration ( $\mathrm{mg} / \mathrm{kg} \mathrm{d.m}$.) in cookies baked at $190^{\circ} \mathrm{C}$ for $20 \mathrm{~min}$, as influenced by different salts added in the formulations. Results are expressed in dry matter (d.m.). Values are mean $\pm S D(n=2)$. Different letters mean significant differences $(p<0.05)$. SR: salt replacer.

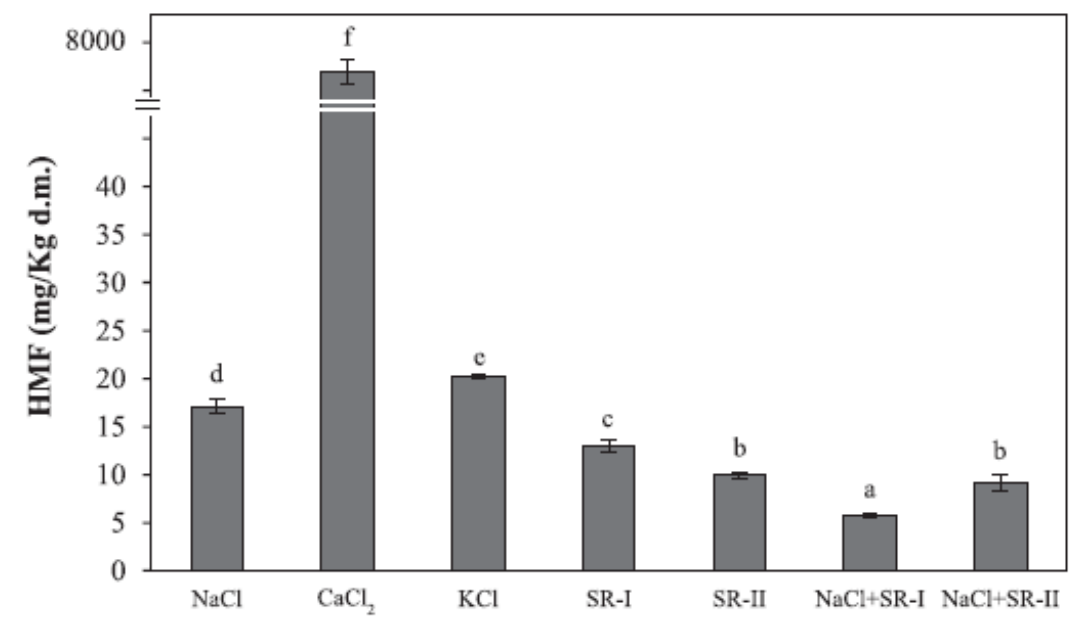


Figure 3. Oxidative parameters in extracted lipids from cookie models stored at $25-30^{\circ} \mathrm{C}$ for 60 days.

\begin{tabular}{lcrlc}
\hline Samples & $\begin{array}{l}\text { Peroxide value } \\
\text { (meq O } / \text { kg lipids) }\end{array}$ & $\begin{array}{l}\text { Dimers (wt\% } \\
\text { on lipids) }\end{array}$ & $\begin{array}{l}\text { Oligomers } \\
\text { (wt\% on lipids) }\end{array}$ & $\begin{array}{l}\text { Total polymers } \\
\text { (wt\% on lipids) }\end{array}$ \\
\hline $\mathrm{NaCl}$ & $3961 \pm 14.8^{\mathrm{g}}$ & $16.4 \pm 0.7^{\mathrm{e}}$ & $5.7 \pm 1.1^{\mathrm{b}}$ & $22.1 \pm 1.8^{\mathrm{f}}$ \\
$\mathrm{CaCl}_{2}$ & $2433 \pm 138.6^{\mathrm{e}}$ & $8.2 \pm 0.2^{\mathrm{c}}$ & $3.2 \pm 0.3^{\mathrm{a}}$ & $11.4 \pm 0.5^{\mathrm{c}}$ \\
$\mathrm{KCl}$ & $805 \pm 178.2^{\mathrm{c}}$ & $3.7 \pm 0.1^{\mathrm{b}}$ & - & $3.7 \pm 0.1^{\mathrm{b}}$ \\
$\mathrm{SR}-\mathrm{I}$ & $393 \pm 1.4^{\mathrm{a}}$ & $1.9 \pm 0.1^{\mathrm{a}}$ & - & $1.9 \pm 0.1^{\mathrm{a}}$ \\
$\mathrm{SR}-\mathrm{II}$ & $2137 \pm 17.7^{\mathrm{d}}$ & $12.3 \pm 0.5^{\mathrm{d}}$ & $3.5 \pm 0.3^{\mathrm{a}}$ & $15.8 \pm 0.6^{\mathrm{d}}$ \\
$\mathrm{NaCl}+\mathrm{SR}-\mathrm{I}$ & $537 \pm 21.2^{\mathrm{b}}$ & $2.0 \pm 0.1^{\mathrm{a}}$ & - & $2.0 \pm 0.1^{\mathrm{a}}$ \\
$\mathrm{NaCl}+\mathrm{SR}-\mathrm{II}$ & $3007 \pm 201.5^{\mathrm{f}}$ & $12.8 \pm 0.4^{\mathrm{d}}$ & $6.0 \pm 0.6^{\mathrm{b}}$ & $18.8 \pm 0.7^{\mathrm{e}}$ \\
\hline
\end{tabular}

Values are mean $\pm \mathrm{SD}(n=2)$. Different letters in the same column mean significant differences $(p<0.05)$. SR: salt replacer, Wt: weight. 